Movere Journal Vol 1 No. 1 Januari 2019 Hal 59-69

MOVERE JOURNAL

http://ojs.stie-tdn.ac.id/index.php/mv

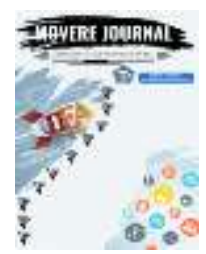

\title{
FAKTOR PENYEBAB KREDIT MACET PADA KOPERASI SIMPAN PINJAM WARGA MAKMUR CABANG MARISA
}

\author{
NG Syamsiah B \\ STIE Ichsan Pohuwato Gorontalo
}

\begin{abstract}
Abstrak : Tujuan penelitian ini adalah untuk mengetahui dan menganalisis faktor internal dan eksternal mempengaruhi kredit macet pada KSP warga Makmur. Hasil penelitian diperoleh hasil persamaan regresi $\mathrm{Y}=-2.041+0.399 \mathrm{X} 1+1.378 \mathrm{X} 2$, ini menunjukkan nilai constant 2,041 yang berarti bahwa kredit macet sebesar 2,041. Koefisien regresi untuk faktor internal sebesar 0,339 yang artinya bahwa kontribusi faktor internal adalah positif atau setiap penurunan faktor internal akan mempengaruhi kredit macet. Koefisien regresi untuk faktor eksternal sebsar 1,378 artinya kontribusi faktor eksternal terhadap kredit macet adalah positif. Setiap penurunan faktor eksternal akan mempengaruhi kredit macet. Olahan data pada program SPSS diperoleh nilai $\mathrm{R}$ Square $\left(\mathrm{r}^{2}\right)$ sebesar 0,573 atau 57,3\%. Yang artinya kontribusi faktor internal dan faktor eksternal mempunyai kontribusi sebesar 57,3\% terhadap kredit macet. Berdasarkan hasil perhitungan regresi berganda yang dilakukan, diperoleh nilai koefisien parsial dari variabel faktor internal (X1) berpengaruh positif tapi tidak signifikan terhadap kredit macet sebesar 0,399. Sedangkan variabel faktor eksternal (X2) berpengaruh positif dan signifikan terhadap kredit macet pada taraf signifikansi $\alpha=0,005<0,000$ sebesar 1,378. Dengan demikian hipotesis yang peneliti ajukan dapat diterima.
\end{abstract}

Kata kunci: kredit macet

\section{PENDAHULUAN}

Koperasi adalah suatu kumpulan orang yang berkumpul secara sukarela untuk usaha bersama mencapai tujuan bersama melalui suatu organisasi yang dikontrol secara demokratis, bersamasama kontribusi sejumlah uang dalam membentuk modal yang diperlukan untuk mencapai tujuan bersama tersebut dan bersedia turut bertanggungjawab menanggung resiko dari kegiatan tersebut, turut menikmati memanfaatkan usaha bersama tersebut sesuai dengan kontribusi permodalan yang diberikan orang-orang tersebut. Kemudian orangorang tersebut secara bersama-sama dan langsung turut memanfaatkan organisasi tadi.

Koperasi lahir pada permulaan abad ke-19, sebagai reaksi terhadap sistem liberalisme ekonomi yang pada waktu itu golongan kecil pemilik modal menguasai kehidupan masyarakat. Pada saat itulah tumbuh gerakan koperasi yang menentang aliran individualisme dengan azas kerjasama dan bertujuan untuk kesejahteraan masyarakat. Koperasi di Indonesia merupakan suatu wadah untuk menyususun perekonomian rakyat yang berdasarkan kekeluargaan dan gotongroyong. Organisasi di Indonesia menjamin hak-hak individu dengan memegang azas demokrasi. Pengertian mengenai azas dan dasar koperasi harus ditinjau dan disesuaikan dengan tujuan negara. Peranan dan kemampuan koperasi harus 
ditingkatkan, untuk meningkatkan kemampuan koperasi perlu dilakukan pembinaan pra-karya meningkatkan keterampilan manajemen, pemupukan dari modal anggota, agar koperasi menjadi wahana untuk meningkatkan kesejahteraan rakyat. Namun, dengan semakin berkembangnya suatu kegiatan perekonomian dan untuk meningkatkan kesejahteraan masyarakat serta untuk mencapai tujuan Negara yaitu mewujudkan masyarakat yang adil dan makmur maka perlu terus dikembangkannya sektor perekonomian, yaitu sektor perekonomian yang mampu mensejahterakan masyarakat.

Kredit atau pembiayaan macet tersebut bisa disebabkan faktor ekstern dan intern dari manajemen KSP Warga Makmur sendiri ataupun dari pihak nasabah (debitur) yang telah mendapat pembiayaan tersebut. KSP Warga Makmur merupakan salah satu sektor perekonomian yang dituntut untuk mampu bersaing dengan bank-bank lain. Salah satu kegiatan utama dan merupakan sumber pendapatan bagi KSP Warga Makmur adalah dengan memberikan jasa pinjaman kredit. Dalam kegiatan operasionalnya, KSP Warga Makmur menghadapi persaingan yang sangat ketat dengan lembaga keuangan lain seperti bank umum maupun bank swasta dan lembaga keuangan lainnya. Penyaluran kredit yang diberikan KSP Warga Makmur supaya terlaksana dengan baik maka pihak manajemen KSP Warga Makmur harus dapat mengambil keputusan yang tepat dalam suatu pemberian kredit kepada calon debitur.

Pemberian kredit bertujuan membantu ketersedian dana untuk membiayai kegiatan produksi nasional, penyimpanan bahan, pembiayaan kredit penjualan, transportasi barang dan kegiatan perdagangan. Peranan perkreditan cukup dominan dalam suatu negara yang sedang berkembang dalam rangka mengembangkan potensi ekonomi. Pemberian kredit yang berjalan lancar akan mengembangkan dan meningkatkan kegiatan ekonomi suatu negara. Kedudukan KSP Warga Makmur sangat rentan dengan adanya pemberian kredit yang didalamnya mengandung "Degree Of Risk" yang tidak menutup kemungkinan terjadinya suatu kredit macet.

Kredit atau pembiayaan macet tersebut bisa disebabkan faktor ekstern dan intern dari manajemen KSP Warga Makmur sendiri ataupun dari pihak nasabah (debitur) yang telah mendapat pembiayaan tersebut. Pemberian fasilitas kredit KSP Warga Makmur dihadapkan pada masalah yaitu resiko kredit yang terdapat kemungkinan kredit yang telah disalurkan tidak kembali sesuai yang dipinjamkan. Penerapan manajemen pemberian kredit dan penagihan kredit yang baik perlu dilakukan untuk mengurangi resiko kredit tersebut. Selain itu, KSP Warga Makmur harus senantiasa menggunakan analisa kredit yang benar. Apabila kegiatan analisis kredit dilakukan dengan benar maka akan terhindar dari resko kredit bermasalah/kredit macet. Kredit macet selain merugikan KSP Warga Makmur tetapi juga dapat membuat KSP Warga Makmur di likuidasi. Hal ini sangat memberikan dampak buruk, sehingga perlu dilakukan upaya penanganan kredit macet yang serius oleh KSP Warga Makmur. Selain itu KSP Warga Makmur wajib menjaga kualitas aktiva produktifnya.

Koperasi adalah suatu kumpulan orang yang berkumpul secara sukarela untuk usaha bersama mencapai tujuan bersama melalui suatu organisasi yang dikontrol secara demokratis, bersamasama kontribusi sejumlah uang dalam membentuk modal yang diperlukan 
untuk mencapai tujuan bersama tersebut dan bersedia turut bertanggungjawab menanggung resiko dari kegiatan tersebut, turut menikmati memanfaatkan usaha bersama tersebut sesuai dengan kontribusi permodalan yang diberikan orang-orang tersebut. Kemudian orangorang tersebut secara bersama-sama dan langsung turut memanfaatkan organisasi tadi.

Koperasi lahir pada permulaan abad ke-19, sebagai reaksi terhadap system liberalisme ekonomi yang pada waktu itu golongan kecil pemilik modal menguasai kehidupan masyarakat. Pada saat itulah tumbuh gerakan koperasi yang menentang aliran individualisme dengan azas kerjasama dan bertujuan untuk kesejahteraan masyarakat. Koperasi di Indonesia merupakan suatu wadah untuk menyususun perekonomian rakyat yang berdasarkan kekeluargaan dan kegotongroyongan. Oraganisasi di Indonesia menjamin hak-hak individu dengan memegang azas demokrasi. Pengertian mengenai azas dan dasar koperasi harus ditinjau dan disesuaikan dengan tujuan negara.

Peranan dan kemampuan koperasi harus ditingkatkan, usaha untuk meningkatkan kemampuan koperasi perlu dilakukan pembinaan prakarya peningkatan keterampilan manajemen, pemupukan dari modal anggota, agar koperasi menjadi wahana untuk meningkatkan kesejahteraan rakyat. Namun, semakin berkembangnya suatu kegiatan perekonomian dan untuk kesejahteraan masyarakat serta untuk mencapai tujuan Negara yaitu mewujudkan masyarakat yang adil dan makmur maka sangat perlu terus dikembangkannya berbagai sektor perekonomian.

Kredit atau pembiayaan macet tersebut bisa disebabkan faktor ekstern dan intern dari manajemen KSP Warga Makmur sendiri ataupun dari pihak nasabah (debitur) yang telah mendapat pembiayaan tersebut. KSP Warga Makmur merupakan salah satu sektor perekonomian yang dituntut untuk mampu bersaing dengan bank-bank lain. Salah satu kegiatan utama dan merupakan sumber pendapatan bagi KSP Warga Makmur adalah dengan memberikan jasa pinjaman kredit. Dalam kegiatan operasionalnya, KSP Warga Makmur menghadapi persaingan yang sangat ketat dengan lembaga keuangan lain seperti bank umum maupun bank swasta dan lembaga keuangan lainnya. Penyaluran kredit yang diberikan KSP Warga Makmur supaya terlaksana dengan baik maka pihak manajemen KSP Warga Makmur harus dapat mengambil keputusan yang tepat dalam suatu pemberian kredit kepada calon debitur.

Pemberian kredit bertujuan membantu ketersedian dana untuk membiayai kegiatan produksi nasional, penyimpanan bahan, pembiayaan kredit penjualan, transportasi barang dan kegiatan perdagangan. Peranan perkreditan cukup dominan dalam suatu negara yang sedang berkembang dalam rangka mengembangkan potensi ekonomi. Pemberian kredit yang berjalan lancar akan mengembangkan dan meningkatkan kegiatan ekonomi suatu negara. Kedudukan KSP Warga Makmur sangat rentan dengan adanya pemberian kredit yang didalamnya mengandung "Degree Of Risk" yang tidak menutup kemungkinan terjadinya suatu kredit macet.

Kredit atau pembiayaan macet tersebut bisa disebabkan faktor ekstern dan intern dari manajemen KSP Warga Makmur sendiri ataupun dari pihak nasabah (debitur) yang telah mendapat pembiayaan tersebut. Pemberian fasilitas kredit KSP Warga Makmur dihadapkan pada masalah yaitu resiko kredit yang terdapat kemungkinan 
kredit yang telah disalurkan tidak kembali sesuai yang dipinjamkan. Penerapan manajemen pemberian kredit dan penagihan kredit yang baik perlu dilakukan untuk mengurangi resiko kredit tersebut. Selain itu, KSP Warga Makmur harus senantiasa menggunakan analisa kredit yang benar. Apabila kegiatan analisis kredit dilakukan dengan benar maka akan terhindar dari resko kredit bermasalah/kredit macet. Kredit macet selain merugikan KSP Warga Makmur tetapi juga dapat membuat KSP Warga Makmur di likuidasi. Hal ini sangat memberikan dampak buruk, sehingga perlu dilakukan upaya penanganan kredit macet yang serius oleh KSP Warga Makmur. Selain itu KSP Warga Makmur wajib menjaga kualitas aktiva produktifnya.

\section{LANDASAN TEORI Pengertian Kredit}

Istilah kredit sebenarnya memiliki makna yang beraneka ragam. Berawal dari kata "kredit" yang berasal dari bahasa Yunani "credere" yang mempunyai arti "kepercayaan" sedangkan dalam bahasa Latin "creditum" yang berarti kepercayaan akan kebenaran. Kredit dalam arti luas adalah kemampuan untuk melaksanakan suatu pembelian atau mengadakan suatu pinjaman dengan suatu janji pembayaran yang akan dilakukan ditangguhkan pada suatu jangka waktu yang disepakati (Mulyono dalam Irham Fahmi 2014:90).

\section{Unsur-Unsur Kredit}

Menurut Kasmir

(2012:87)

terdapat unsur-unsur yang terkandung dalam pemberian suatu fasilitas kredit yaitu:

1. Kepercayaan

Yaitu suatu keyakinan pemberian kredit bahwa kredit yang diberikan (berupa uang, barang, atau jasa) akan benar-benar diterima kembali dimasa datang. Kepercayaan ini diberikan oleh perusahaan, dimana sebelumnya sudah dilakukan penelitian penyelidikan tentang nasabah baik secara intern maupun ekstern. Penelitian dan penyelidikan tentang kondisi masa lalu dan sekarang terhadap nasabah pemohon kredit.

2. Kesepakatan

Disamping kepercayaan di dalam kredit juga mengandung unsure kesepakatan antara si pemberi kredit dengan si penerima kredit. Kesepakatan ini dituangkan dala suatu perjanjian dimana masingmasing pihak menandatangani hak dan kewajibannya masing-masing.

3. Jangka Waktu

Setiap kredit yang diberikan memiliki jangka waktu tertentu, jangka waktu ini mencakup masa pengembalian kredit yang telah disepakati. Jangka waktu tersebut bisa berbentuk jangka pendek, jangka menengah, atau jangka panjang.

4. Risiko

Adanya suatu tenggang waktu pengembalian akan menyebabkan suatu risiko tidak tertagihnya/macet pemberian kredit. Semakin panjang suatu kredit semakin besar risikonya demikian pula sebaliknya. Risiko inin menjadi tanggung jawab perusahaan, baik risiko yang disengaja oleh nasabah yang lalai maupun oleh risiko yang tidak disengaja. Misalnya terjadi bencana alam atau bangkrutnya usaha nasabah tanpa ada unsure kesengajaan lainnya.

5. Balas Jasa

Merupakan keuntungan atas pemberian suatu kredit atau jasa tersebut yang kita kenal dengan nama bunga. Balas jasa dalam bentuk ini merupakan keuntungan 
perusahaan.

\section{Manfaat Kredit}

Manfaat kredit menurut Mulyono (2003:63) dalam bukunya Manajemen Perkreditan Bagi Perusahaan Komersial antara lain:

1. Ditinjau Dari Kepentingan Debitur

a. Relatif mudah diperoleh kalau memang usahanya betul-betul feasible.

b. Telah ada lembaga penyedia dana (kredit).

c. Terdapat berbagai jenis kredit, berbagai bentuk penawaran modal (dana) hingga dapat dipilih dana yang paling cocok untuk kebutuhan modal perusahaan yang bersangkutan.

d. Dengan fasilitas kredit memungkinkan para debitur untuk memperluas dan mengembangkan usahanya dengan lebih leluasa.

2. Ditinjau Dari Sudut Kepentingan Perusahaan

a. Memperoleh pendapatan bunga kredit.

b. Untuk menjaga sovabilitas usahanya.

c. Dengan memberikan kredit akan membantu memasarkan jasa-jasa perperusahaanan yang lain.

d. Pemberian kredit untuk mempertahankan dan mengembangkan usahanya.

e. Pemberian kredit untuk merebut pasar dalam industri perperusahaanan.

3. Ditinjau Dari Kepentingan Pemerintah

a. Sebagai alat memacu pertumbuhan ekonomi baik secara umum maupun untuk pertumbuhan sektor ekonomi tertentu.

b. Sebagai alat untuk mengendalikan kegiatan moneter. c. Sebagai alat untuk menciptakan lapangan usaha/kegiatan.

d. Alat peningkatan dan pemerataan pendapatan masyarakat.

e. Sumber pendapatan negara.

f. Penciptaan pasar, dll.

4. Ditinjau Dari Kepentingan Masyarakat Luas

a. Diharapkan kan diperoleh adanya pertumbuhan ekonomi yang pesat dan membuka lapangan kerja baru, sehingga akan menimbulkan kenaikan tingkat pendapatan dan pemerataan pendapatan di masyarakat.

b. Dengan semakin banyaknya proyek dan perusahaan yang dibuka kerena memperoleh fasilitas kredit sudah tentu akan menyerap banyak tenaga kerja baru.

c. Dengan dibuka/didirikannya perusahaan baru akan menimbulkan tumbuhnya usaha-usaha lain yang mempunyai kaitan erat dengan perusahaan tersebut.

\section{Prinsip-prinsip Pemberian Kredit}

Menurut Martono (2004:81), prinsip perkreditan disebut juga sebagai konsep 5C dan 7P. Adapun penjelasan untuk analisis kredit dengan prinsip 5C adalah sebagai berikut:

1. Character Pada prinsip ini diperhatikan dan diteliti tentang kebiasaan-kebiasaan, sifat-sifat pribadi, cara hidup (style of living), keadaan keluarganya (anak istri), hobby dan social standing calon debitur. Prinsip ini merupakan ukuran tentang kemauan untuk membayar (wiliingnes to pay).

2. Capacity

Penilaian terhadap capacity debitur dilakukan untuk mengetahui sejauh mana kemampuan debitur mengembalikan pokok pinjaman 
serta bunga pinjamannya. Penilaian kemampuan membayar tersebut dilihat dari kegiatan usaha dan kemampuannya melakukan pengelolaan atas usaha yang akan dibiayai dengan kredit.

3. Capital

Penyelidikan terhadap prinsip capital atau permodalan debitur tidak hanya melihat besar kecilnya modal tersebut, tetapi juga bagaimana distribusi modal itu ditempatkan oleh debitur. Cukupkan modal yang tersedia sehingga segala sumber dapat bergerak secara efektif. Baikkah pengaturan modal itu sehingga perusahaan berjalan lancar dan maju. Berapa besar modalnya? Kesemuanya ini dapat dilihat dari posisi neraca perusahaan calon debitur.

4. Collateral

Penilaian terhadap barang jaminan (collateral) yang diserahkan debitur sebagai jaminan atas kredit perusahaan yang diperolehnya adalah untuk mengetahui sejauh mana nilai barang jaminan atau agunan dapat menutupi risiko kegagalan pengembalian kewajiban-kewajiban debitur. Fungsi jaminan disini adalah sebagai alat pengaman terhadap kemungkinan tidak mampunya debitur melunasi kredit yang diterimanya.

5. Condition

Pada prinsip kondisi (condition), yang dinilai kondisi ekonomi secara umum serta kondisi sektor usaha calon debitur. Maksudnya agar perusahaan dapat memperkecil risiko yang mungkin timbul oleh kondisi ekonomi, keadaan perdagangan dan persaingan di lingkungan sektor usaha calon debitur dapat diketahui, sehingga bantuan yang akan diberikan benar-benar bermanfaat bagi perkembangan usahanya. Kondisi ekonomi ini termasuk pula peraturan-peraturan atau kebijakan pemerintah yang memiliki dampak terhadap keadaan perekonomian yang pada gilirannya akan mempengaruhi kegiatan usaha debitur.

Sedangkan penjelasan analisa prinsip-prinsip 7P dalam kredit adalah sebagai berikut:

1. Personality

Perusahaan mencari data tentang kepribadian calon debitur seperti riwayat hidupnya (kelahiran, pendidikan, pengalaman, usaha/ pekerjaan dan sebagainya), hobby, keadaan keluarga, pegaulan dalam masyarakat (social standing) dan hal-hal lainnya yang berhubungan dengan kepribadian calon debitur.

2. Purpose

Perusahaan mencari data tentang tujuan atau keperluan penggunaan kredit. Apakah akan digunakannya untuk berdagang, berproduksi, atau membeli rumah. Apakah tujuan penggunaan kredit sesuai dengan line of business kredit perusahaan yang bersangkutan.

3. Prospect

Merupakan harapan masa depan dari bidang usaha atau kegiatan usaha calon debitur selama beberapa bulan atau beberapa tahun, perkembangan keadaan ekonomi/perdagangan keadaan sektor usaha calon debitur, kekuatan keuangan perusahaan masa lalu dan perkiraan masa mendatang.

4. Payment

Merupakan prinsip untuk mengetahui bagaimana pembayaran kembali pinjaman yang akan diberikan. Hal ini dapat diperoleh dari perhitungan tentang prospect, kelancaran penjualan dan 
pendapatan sehingga dapat diperkirakan kemampuan pengembalian pinjaman ditinjau dari waktu serta jumlah pengembaliannya.

5. Party

Merupakan pengelompokan nasabah kedalam klasifikasi tertentu atau golongn-golongan tertentu berdasarkan modal, loyalitas serta karakternya. Dengan demikian nasabah dapat disolongkan ke golongan tertentu dan akan mendapat fasilitas kredit yang berbeda pula dari perusahaan, baik dari segi jumlah, bunga, dan persyaratan lainnya.

6. Profitability

Merupakan kemapuan nasabah dalm mencari laba. Profitability diukur dari perode ke periode apakah kan tetap sama atau semakin meningkat, apalagi dengan tambahan kredt yang akan diperolehnya dari perusahaan.

7. Protection

Tujuannya adalah bagaimana menjaga kredit yang dikucurkan oleh perusahaan melalui suatu perlindungan. Perlindungan ini dapat berupa jaminan barang atau orang atau jaminan asuransi.

\section{Kredit Macet}

Kredit macet dapat diartikan sebagai pinjaman yang mengalami kesulitan pelunasan akibat adanya faktor kesengajaan dan atau karena faktor eksternal diluar kemampuan kendali debitur (Dahlan, 2001:174). Sedangkan menurut Veithzal Riva ${ }^{\text {eci }}$ (2008:477) kredit macet merupakan kesulitan nasabah di dalam penyelesaian kewajiban-kewajibannya terhadap perusahaan, baik dalam bentuk pembayaran kembali pokoknya, pembayaran bunga, maupun pembayaran ongkos-ongkos perusahaan yang menjadi beban nasabah debitur yang bersangkutan.
Dari pengertian tersebut dapat disimpulkan bahwa kredit macet sebagai pinjaman yang mengalami kesulitan dalam penyelesaian kewajiban-kewajibannya oleh nasabah debitur terhadap perusahaan karena faktor kesengajaan dan atau karena faktor eksternal diluar kemampuan kendali debitur.

\section{Faktor-Faktor Penyebab Kredit Macet}

Menurut Mahmoedin (2000:134), faktor-faktor yang menyebabkan kredit macet dilihat dari segi pelaku kredit adalah sebagai berikut :

1. Kelemahan nasabah
a. Manajemen kurang (kurang menguasai manajemen kredit)
b. Tidak memiliki perencanaan yang baik
c. Produk ketinggalan jaman
d. Kalah bersaing
e. Lokasi usaha yang tidak tepat
f. Administrasi yang kacau

2. Kenakalan nasabah
a. Tidak jujur dan sukar ingkar janji
b. Melakukan penyimpangan penggunaan
c. Pola hidup yang boros atau mewah
d. Suka berbuat skandal
e. Suka berjudi dan berspekulasi.

Kemacetan kredit menurut Sinungan (2000:240) disebabkan oleh kesulitan-kesulitan keuangan yang dialami nasabah yang timbul karena berbagai faktor. Faktor yang paling besar pengaruhnya adalah karena inefisiensi dari pimpinan perusahaan dimana pimpinan perusahaan mempunyai berbagai kelemahan dalam pengelolaan perusahaan, kelemahan dalam kontrol ataupun kesalahan dalam penentuan policy perusahaan.

Penyebab dari kesulitan-kesulitan keuangan perusahaan yang 
mengakibatkan suatu kemacetan kredit dibagi dalam dua kategori :

1. Faktor-faktor Intern (Managerial Factor).

Faktor-faktor intern adalah faktorfaktor yang ada dalam diri perusahaan sendiri, dari segi managerial factor terjadinya kredit macet disebabkan oleh :
a. Kelemahan
kebijaksanaan pembelian dan penjualan dalam
b. Tidak efektifnya kontrol atas biaya dan pengeluaran.
c. Kebijaksanaan tentang kebijaksanaan piutang yang tidak efektif
d. Penempatan yang berlebihan pada aktiva tetap
e. Permodalan yang tidak cukup.

\section{Faktor-faktor Ekstern}

Faktor-faktor ekstern adalah faktorfaktor yang berasal dari luar perusahaan, faktor-faktor ekstern meliputi :

a. Bencana Alam

Bencana alam adalah sesuatu yang tidak kita inginkan. Misalnya kebakaran, gempa bumi, gunung meletus, angin topan, banjir, dan sebagainya.

b. Peperangan

Perang merupakan pengrusakan dan akibat dari peperangan ini merupakan bencana yang diperbuat manusia, misal demonstrasi, penjarahan, pembakaran dan lainlain.

c. Perubahan kondisi perekonomian Misalnya peraturan pemerintah terhadap suatu jenis barang, keadaan kritis misalnya kenaikan tarif dasar listrik, pajak dan lainlain.

d. Perubahan teknologi

Semakin majunya teknologi maka semakin efisien barang yang diproduksi sehingga perusahaan yang tidak menggunakan teknologi modern akan kalah bersaing.

\section{Teknik Penyelesaian Kredit Macet}

Tindak lanjut dalam mengatasi kredit macet yang dapat dilakukan oleh pihak bank dengan melakukan penyelamatan, sehingga tidak akan menimbulkan kerugian. Penyelamatan dapat dilakukan dengan memberikan keringanan berupa jangka waktu pembayaran atau jumlah angsuran terutama bagi kredit terkena musibah atau dengan melakukan penyitaan bagi kredit yang sengaja lalai untuk membayar. Penyelamatan terhadap kredit macet menurut Kasmir (2002:103) dilakukan dengan beberapa metode yaitu:

1. Rescheduling, yaitu dengan cara :

a. Memperpanjang jangka waktu kredit, dalam hal ini nasabah diberikan keringanan dalam masalah jangka waktu kredit, misalnya perpanjangan jangka waktu kredit dari 6 bulan menjadi 1 tahun sehingga nasabah mempunyai waktu yang lebih lama untuk mengembalikannya.

b. Memperpanjang jangka waktu angsuran, dalam hal ini jangka waktu angsuran kreditnya diperpanjang pembayarannya, misalnya dari 36 kali menjadi 48 kali.

2. Reconditioning, dengan cara mengubah berbagai persyaratan yang ada seperti:

a. Kapasitas bunga, yaitu dengan cara bunga dijadikan hutang pokok.

b. Penundaan pembayaran bunga sampai waktu tertentu, maksudnya hanya bunga yang dapat ditunda pembayarannya, sedangkan pokok pinjamannya harus dibayar seperti biasa.

c. Penurunan suku bunga, penurunan suku bunga akan 
dipengaruhi jumlah angsuran yang semakin kecil, sehingga diharapkan dapat membantu meringankan nasabah.

d. Pembebasan bunga, hal ini diberikan kepada nasabah dengan mempertimbangkan nasabah sudah tidak akan mampu lagi membayar kredit tersebut. Akan tetapi nasabah tetap mempunyai kewajiban untuk membayar pokok pinjaman sampai lunas.

3. Restructuring, yaitu dengan cara :

a. Menambah jumlah kredit

b. Menambah equity yaitu dengan menyetor uang tunai serta tambahan dari pemilik.

4. Kombinasi, merupakan kombinasi dari ketiga metode diatas.

Penyitaan jaminan, merupakan jalan terakhir apabila nasabah sudah benar-benar tidak punya itikad baik atau sudah tidak mampu lagi untuk membayar semua hutang-hutangnya.

\section{METODE PENELITIAN}

\section{Jenis dan Sumber Data}

Data yang digunakan dalam penelitian ini adalah data primer dan data sekunder. Data primer yang digunakan adalah hasil dari kuesioner yang dibagikan pada nasabah (responden). Sedangkan untuk data sekunder yang digunakan dalam penelitian ini adalah data yang telah diolah oleh pihak lain meliputi informasi dari media elektronik (internet), literature dari perpustakaan serta hasil penelitian terdahulu.

\section{Metode Pengumpulan Data}

a. Observasi, Penulis mengadakan pengamatan secara langsung untuk memperoleh data yang besifat kualitatif dan kuantitatif

b. Wawancara, Penulis mengadakan wawancara kepada pihak-pihak yang bersangkutan dalam perusahaan. c. Dokumentasi,

Penulis

mengumpulkan data atau

dokumen-dokumen yang terdapat pada KSP Warga Makmur Cabang Marisa.

\section{Populasi}

Populasi dalam penelitian ini adalah nasabah yang ada di KSP Warga Makmur cabang Marisa yang berjumlah 20 orang responden. Metode pengambilan sampel dalam penelitian ini menggunakan sampling jenuh (sensus). Menurut Sugiyono (2004:44) sampling jenuh adalah teknik pengambilan sampel bila semua anggota populasi digunakan sebagai sampel karena jumlah populasi kecil dan relatif heterogen.

\section{HASIL DAN PEMBAHASAN Analisis Regresi}

Berdasarkan pada hasil olahan data dengan menggunakan program SPSS maka diperoleh hasil persamaan regresi sebagai berikut :

$$
\mathrm{Y}=-2.041+0.399 \mathrm{X} 1+1.378 \mathrm{X} 2
$$

Nilai constant (a) sebesar 2.041 yang berarti jika niali constant diabaikan dalam hal ini kredit macet pada KSP Warga Makmur, maka kredit macet sebesar -2.041 yang juga dijadikan tolak ukur. Yang artinya setiap peningkatan satu satuan kinerja, maka kredit macet pada KSP Warga Makmur mengalami peningkatan sebesar 2.041 satuan.

Nilai X1 sebesar 0,339 yang berarti faktor Intern berpengaruh positif terhadap kredit macet sebesar 0,339 yang berarti faktor intern meningkat, maka akan di ikuti dengan peningkatan krediot macet sebesar 0,339 atau $33,9 \%$.

Sedangkan nilai X2 sebesar 1,378 yang berarti faktor ekstern berpengaruh positif terhadap kredit macet sebesar 1,378 yang berarti jika faktor ekstern meningkat, maka akan diikuti dengan peningkatan kredit 
macet sebesar 1,378 atau $13,78 \%$. Sehingga hasil perhitungan regresi berganda di atas menunjukkan bahwa variabel faktor internal (X1) dan variabel faktor eksternal (X2) berpengaruh positif terhadap kredit macet (Y) dan variabel yang paling dominan kontribusinya terhadap variabel kredit macet (Y) adalah variabel faktor eksternal (X2) yaitu sebesar 1,378 atau $13,78 \%$.

\section{Uji Simultan (Uji F)}

Sebagaimana hipotesis yang diajukan pada Bab II bahwa, variabel faktor internal (X1) dan variabel faktor eksternal (X2) berpengaruh positif terhadap kredit macet (Y) pada KSP Warga Makmur. Untuk menguji hipotesis tersebut digunakan uji simultan atau uji $\mathrm{F}$ pada tingkat signifikansi $\alpha=5 \%$. Uji F dilakukan dengan cara membanding kan antara nilai sig. dengan derajat alpha pada taraf signifikan 5\%.

Hasil perhitungan regresi linear berganda yang dilakukan dengan menggunakan alat bantu program SPSS dapat diketahui bahwa nilai sig. $=0,001<$ derajat $\alpha=0,05$ yang artinya faktor internal (X1) dan variabel faktor eksternal (X2) pada KSP Warga Makmur menunjukkan bahwa faktor internal (X1) dan variabel faktor eksternal (X2) secara simultan berpengaruh positif dan signifikan terhadap kredit macet (Y) pada KSP Warga Makmur. Dengan demikian hipotesis yang diajukan pada penelitian ini dapat diterima. Sedangkan kontribusi variabel faktor internal (X1) dan variabel faktor eksternal (X2) secara bersama-sama mempengaruhi kredit macet dapat dilihat pada besarnya koefisien determinasi $\left(\mathrm{R}^{2}\right)$ sebesar 0,573 atau $57,3 \%$.

Olahan data pada program SPSS diperoleh nilai $R$ Square $\left(r^{2}\right)$ sebesar
0,573 atau 57,3\%. Yang artinya kontribusi faktor internal (X1) dan variabel faktor eksternal (X2) mempunyai kontribusi sebesar 57,3\% terhadap kredit macet sedangkan sisanya $42,7 \%$ dipengaruhi oleh faktorfaktor lain yang tidak diteliti.

\section{Uji Parsial (Uji t)}

Uji t digunakan untuk mengetahui bagaimana pengaruh faktor intern (X1) dan variabel faktor ekstern (X2) pada KSP Warga Makmur. Uji t dilakukan dengan cara membandingkan niali sig. dengan derajat $\alpha=5 \%$ atau 0,005 . Jika nilai sig. $<0,05$ maka dapat disimpulkan bahwa variabel tersebut memiliki pengaruh yang signifikan.

Berdasarkan hasil perhitungan regresi berganda yang dilakukan, diperoleh nilai koefisien parsial dari masing-masing variabel independen dijelaskan bahwa faktor internal (X1) berpengaruh positif namun tidak signifikan terhadap kredit macet sebesar 0,399. Sedangkan faktor eksternal (X2) berpengaruh positif dan signifikan terhadap kredit macet pada taraf signifikansi $\alpha=0,005<0,000$ sebesar 1,378. Dengan demikian hipotesis yang peneliti ajukan dapat diterima.

\section{KESIMPULAN}

Berdasarkan hasil penelitian dan pembahasan dapat ditarik kesimpulan bahwa :

1. Faktor internal (X1) dan variabel faktor eksternal (X2) secara simultan berpengaruh positif dan signifikan terhadap kredit macet (Y) pada KSP Warga Makmur.

2. Sedangkan kontribusi variabel faktor internal (X1) dan variabel faktor eksternal (X2) secara bersama-sama mempengaruhi kredit macet dapat dilihat pada besarnya koefisien determinasi $\left(\mathrm{R}^{2}\right)$ sebesar 0,573 atau $57,3 \%$ dan 
3. Variabel yang paling dominan kontribusinya terhadap variabel kredit macet (Y) adalah variabel faktor eksternal (X2) yaitu sebesar 1,378 atau $13,78 \%$.

\section{DAFTAR PUSTAKA}

Dahlan Siamat. 2001. Manajemen Lembaga Keuangan, Edisi Ketiga, Fakultas Ekonomi Indonesia, Jakarta.

Fahmi, Irham. 2014. Analisis Laporan Keuangan. Bandung: Alfabeta.

Kasmir. 2012. Analisis Laporan Keuangan. Cetakan Keenam. Jakarta : PT. Raja Grafindo.

Pudjo Mulyono, Teguh. (2003). Manajemen Perkreditan. Yogyakarta : BPFP.

Rivai Veithzal, 2008, Manajemen Sumber Daya Manusia Untuk Perusahaan : dari Teori dan Praktik, PT. RajaGrafindo Persada, Jakarta.

Sugiyono. 2000. Metode Penelitian Bisnis. Cetakan Kelima : Penerbit CV. Alfabeta: Bandung

Sugiyono. 2004. Metode Penelitian Bisnis : Penerbit CV. Alfabeta: Bandung 